University of North Florida

UNIVERSITY of

NORTH FLORIDA.

UNF Digital Commons

Exceptional, Deaf, and Interpreter Education

Faculty Publications

Department of Exceptional, Deaf, and

Interpreter Education

Summer 2004

\title{
An Ecobehavioral Assessment of the Teaching Behaviors of Teacher Candidates During Their Special Education Internship Experiences
}

\author{
Len Roberson \\ University of North Florida, len.roberson@unf.edu \\ M Lynn Woolsey \\ Janice Seabrooks \\ University of North Florida, janice.seabrooks-blackmore@unf.edu \\ Gwen Williams
}

Follow this and additional works at: https://digitalcommons.unf.edu/eexc_facpub

Part of the Special Education and Teaching Commons

\section{Recommended Citation \\ https://digitalcommons.unf.edu/eexc_facpub/3 \\ This Article is brought to you for free and open access by \\ the Department of Exceptional, Deaf, and Interpreter \\ Education at UNF Digital Commons. It has been accepted \\ for inclusion in Exceptional, Deaf, and Interpreter \\ Education Faculty Publications by an authorized \\ administrator of UNF Digital Commons. For more \\ information, please contact Digital Projects. \\ (C) Summer 2004 All Rights Reserved}

Roberson, Len; Woolsey, M Lynn; Seabrooks, Janice; and Williams, Gwen, "An Ecobehavioral Assessment of the Teaching Behaviors of Teacher Candidates During Their Special Education Internship Experiences" (2004). Exceptional, Deaf, and Interpreter Education Faculty Publications. 3.

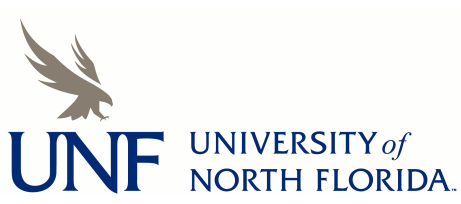


Running head: ECOBEHAVIORAL ASSESSMENT OF SPECIAL EDUCATION TEACHER CANDIDATES

An Ecobehavioral Assessment of the Teaching Behaviors of Teacher Candidates During Their Special Education Internship Experiences

Len Roberson, M. Lynn Woolsey, and Janice Seabrooks University of North Florida

Gwen Williams

Florida A\&M University

Author's Note:

This is a post-review but pre-publication, final version of this manuscript.

The article will be published in the Teacher Education and Special Education.

Roberson, L., Woolsey, M., Seabrooks, J., \& Williams, G. (2004). An ecobehavioral assessment of teaching behaviors of teacher candidates during their internship experiences. Teacher Education and Special Education, 27(3), 264-275. 
Correspondence should be directed to Len Roberson, University of North Florida, 1 UNF Drive, Jacksonville, Florida 32224. E-mail: len.roberson@unf.edu.

\begin{abstract}
In the last 20 years, teacher preparation programs have come under close scrutiny by the public and governmental agencies charged with monitoring teacher quality and the academic achievement of American students. Both regular and special education teacher preparation programs struggle with the requirement to collect valid and reliable evidence of teacher candidate performance and their effect on student learning. This study incorporated an ecobehavioral assessment tool (MSCISSAR) in the evaluation of 13 special education teacher candidates during their internship experiences. Special education teacher candidates taught in deaf education classrooms and self-contained and resource rooms for students with disabilities. Results showed that the instructional arrangements, teaching behaviors and student responses were similar to studies using inservice teachers and students with disabilities as subjects. The incorporation of data gathered through the MS-CISSAR program could be used to meet university and NCATE requirements for evidence of teacher candidate performance.
\end{abstract}


An Ecobehavioral Assessment of the Teaching Behaviors of

Special Education Teacher Candidates During Their Internship Experiences

In today's political climate, teacher instruction and student achievement are often seen as two sides of the same coin. If teachers do their job, students will achieve. If students do not achieve, then teachers are not doing their job. Although many educators balk at the simplistic explanation, public opinion is clear. Sixtyeight percent of Americans believe that every state in America should require a nationally standardized test to measure student achievement. Fifty-three percent favored using a single test to determine student promotion to the next grade. Fiftyseven percent supported a test to determine if students should graduate from high school (Rose \& Gallup, 2002).

The public is not off the mark in their demands for teachers who can demonstrate educational excellence in the classroom. Qualified teachers have a significant impact on student learning (see Darling-Hammond, 2000). What teachers know and what teachers can do in the classroom have significant influence on what students learn (National Commission on Teaching and America's Future, 1996). With that knowledge in the minds of educational policymakers in America, high-stakes testing and teacher accountability are inextricably intertwined. Unfortunately, many schools, teachers, and teacher preparation programs remain unprepared to deliver the quality of educational excellence demanded by the public. 
Expectations of accountability have changed in the last few years.

Teachers have responded in a variety of ways. Some teachers strive to improve their use of instructional strategies considered "best practice" by researchers (Vogler, 2002) while teachers lament the atrophy of their creative talents. Many teachers simply leave the field (Tye \& O'Brien, 2002). Accountability pressures have filtered down to teacher candidates. In a study of what teacher candidates fear most about their first year of teaching, Gee (2001) found that $45 \%$ of the teacher interns indicated fears around "accountability" (planning and implementing state standards and the state-mandated assessment test).

Teacher candidate fears around accountability may in part, stem from perceived weaknesses in teacher training programs. The U.S. Secretary of Education, in the Annual Report on Teacher Quality, (U.S. Department of Education, 2002), stated that teacher education and certification are not related to teacher effectiveness. Although many researchers disagree (see DarlingHammond \& Youngs, 2002), it remains likely that many of today's teacher education programs are unprepared to provide the kind of training, data collection and support to help teacher candidates learn to manage the pressures of being a classroom teacher in the $21^{\text {st }}$ century (Wise \& Liebbrand, 2000).

Beginning in 2000, Colleges of Education accredited by The National Council for Accreditation of Teacher Education (NCATE) must provide multiple samples of reliable and valid evidence that their teacher candidates in regular and 
special education have mastery of content knowledge in their respective fields, pedagogical knowledge and the effect of the instruction of teacher candidates on student learning. NCATE requires teacher training programs to assess the effectiveness of their programs and use that information to improve aspects of their programs. Teacher training programs are expected to set benchmarks for acceptable teacher performance.

Although evidence of grade point averages, Graduate Record Exam scores, portfolios, lesson plans, written reflections, and videos of classroom performance are accepted by NCATE as evidence of teaching expertise, as are data on state licensing exam scores, employer evaluations, and placement rates, the NCATE suggestions provide few measurements of actual teacher performance. Only the videotape sample can show demonstrable evidence that the teacher candidate can actually teach. Further, the No Child Left Behind Act (2001) requires teacher education programs to file formal reports summarizing teacher test results for teacher candidates graduating from their programs. These summary data must also be shared with the public, and states are required to rank order teacher education programs based on these data.

Many Colleges of Education have few alternatives for assessment of teaching performance. Indeed, most schools of education have yet to design assessments of actual teaching performance that outline acceptable and unacceptable performance levels (Wise \& Liebbrand, 2000). In other words, the 
NCATE guidelines come up short when helping us answer the question, "can this teacher candidate effectively teach?" The evidence considered acceptable to NCATE may focus more heavily on evidence of "teacher quality," rather than "teaching quality." Yet, how well a teacher candidate teaches is critical. The quality of teacher preparation can account for $40 \%-60 \%$ of the total variance in student achievement after accounting for student demographics (DarlingHammond, 2000).

Effective Teaching and Academic Achievement

Researchers over the last three decades have found that academic achievement is, in part, a function of time spent learning the content area combined with the level of active academic responding in tasks that are directly related to the skills that will ultimately be assessed as evidence of academic achievement (Greenwood, Carta, Kamps, \& Arreaga-Mayer, 1990). There is a clear correlation between academic gain and academic responding in the classroom.

Several studies have described academic responding specifically as reading, (both aloud and silently), writing, academic talk, and task participation, such as manipulating counters for math or using a computer mouse. Academic responding, defined in this manner, has been positively correlated with achievement on standardized tests (Bulgren \& Carta, 1993; Greenwood, 1991; Greenwood et al., 1990). In 1994, Greenwood, Terry, Marquis and Walker 
provided evidence of a causal path between, academic responding, academic achievement and teacher instruction. Low levels of academic responding have been associated with school failure (Cooper \& Speece, 1990). However, effective instructional practices have been positively correlated with engaged behavior (Greenwood et al., 1990) and various instructional procedures have been identified as positively or negatively influencing academic responding (Greenwood, Delquadri, Stanley, Sasso, \& Whoroton, 1981). Using the right tool, student academic responding is a classroom variable that can be observed and measured.

\section{Ecobehavioral Assessment}

\section{The Ecobehavioral Assessment Instrument}

An ecobehavioral assessment is a conceptual system of analysis designed to measure behaviors in one or more environments. An ecobehavioral assessment focuses on alternately sampling ecological and behavioral variables and systematically recording them in close temporal sequence. Analysis can reveal both sequential and concurrent interrelationships between the environment and a person's responses (Greenwood, Schulte, Dinwiddie, Kohler, \& Carta, 1986).

Using an ecobehavioral assessment tool that incorporates a momentary time sampling method, the effects of teachers' choices for instructional methods, instructional delivery, instructional arrangements, and teacher-student interactions are seen in the context of what the students do (academically respond, manage 
tasks, or engage in competing behaviors). Measures of the teacher's behavior and a target student's behavior in the context of the classroom and instruction are recorded sequentially and repeatedly. The primary focus for ecobehavioral assessment is the identification of the variables surrounding the presence of student academic responding or engagement.

Assuming academic responding is correlated with achievement on standardized tests and assuming that we can effectively measure levels of academic responding in students, we should be able to use an ecobehavioral assessment tool to capture the effects of the instruction provided by teacher candidates in the same manner that we collect data on practicing teachers. Using an ecobehavioral assessment tool, teacher educators in special education may have the capability of observing teacher candidates and charting the covariation of student with disabilities' behaviors in specific environments and in the presence of instructional stimuli.

Ecobehavioral Assessment Tools and Teacher Training

Teacher education programs are expected to find valid and reliable measures of teacher candidate performance, assess the effectiveness of their programs and use that information to improve their programs (Wise \& Liebbrand, 2000). The incorporation of an ecobehavioral assessment tool as a part of the evaluation of preservice teacher candidates can provide valid and reliable data on what the candidates do during a teaching episode. 


\section{Purpose}

This study was a field test of the incorporation of an ecobehavioral assessment tool as part of the evaluation of special education teacher candidates' internship evaluations. The purposes of the present study were to (a) field test the appropriateness and usability of an ecobehavioral assessment (EBASS) tool as a tool for assessment of teaching behaviors in teacher candidates in special education; and (b) describe the teacher behaviors, the ecological and instructional arrangements used by teacher candidates in special education, and the behaviors of the randomly selected students they taught.

\section{Research Questions}

The study was guided by the following research questions:

1. In what ways can ecobehavioral assessment data collected on special education teacher candidates during their internship experiences be incorporated as an assessment of their teaching behaviors?

2. What are the ecological arrangements (instructional grouping, and tasks) used by the selected teacher candidates?

3. What teacher behaviors are most commonly incorporated into lessons taught by teacher candidates? 
4. To what extent do the behaviors of randomly selected target students represent the following categories: academic responses, task management responses, and competing responses?

Method

\section{Participants}

Participants were recruited from the pool of students preparing for internship in the fall of 2002 at an urban university in the southeast. Each potential participant received a letter describing the study and a description of the process for informed consent. Consenting participants also completed a postresearch survey. Thirteen special education teacher interns participated in this study. Eight of the teacher candidates were majors in deaf education. Five of the teacher candidates were majors in exceptional student education. All participants were candidates in an initial certification degree program, receiving either a bachelor's or a master's degree in education. One target student was randomly selected for each observation.

\section{Settings}

The 13 special education teacher candidates taught students with one or more disabilities in several typical special education settings: Five teacher candidates taught in public schools in the following classrooms: (a) varying exceptionalities (VE) resource room (grades 1-5), (b) self-contained severe emotional disturbance (grades K-3); (c) self-contained severe emotional 
disturbance (grades 4/5), (d) self-contained trainable mentally handicapped (grades 7/8), (e) self-contained physically impaired (grades 3-5). Eight teacher candidates were observed at the residential school for the deaf in the following classrooms: (a) kindergarten; (b) early primary (grades 2/3); (c) middle school special needs (grades 6/7/8); and (d) high school classes.

\section{Instrument}

This study used the Mainstream Code for Instructional Structure and Student Academic Response (MS-CISSAR), one of three programs in the EcoBehavioral Assessment System Software (EBASS) package developed by Juniper Gardens Children's Project (Greenwood \& Shye, 1995). EBASS is a computer software package that includes three computer programs used to observe, assess, and document the effects of instructional interventions used in classroom instruction (Greenwood, Carta, Kamps, Terry, \& Delquadri, 1994). The MSCISSAR program includes 105 codes. Observers used laptop computers to record data during the observations. The MS-CISSAR program is based on a momentary time sampling method of data collection divided into three 20 -second intervals that repeat throughout the observation. Classroom ecology (setting, activity, task, physical and instructional arrangement, and teacher definition) is recorded in the first 20-second interval. Teacher behaviors are recorded during the second 20second interval. Student behaviors are recorded during the third interval. 
Because one purpose of this study was to field test the incorporation of the MS-CISSAR ecobehavioral assessment tool as part of the assessment of teaching behaviors in teacher candidates in special education, observations were yoked to the schedule set by the university supervising teacher. All teacher candidates were observed three times during the semester of their internship. Length of observation ranged from 27 to 66 minutes (mean 38 minutes). One target student was randomly selected for observation during each visit. Each target student was chosen for the observation by using a table of random numbers. Observers recorded only the gender of the student, the grade of the student, the student's classroom, and whether or not the student was from an obvious minority culture. The identity of the target student was revealed to the preservice teacher intern at the end of the observation. No other information was collected on the target students.

\section{Reliability}

\section{Training}

The second author and one observer collected the data. The second author previously completed a three-day training provided by a trainer from the Juniper Gardens Children's Project, the developers of the EBASS software and has conducted two studies using MS-CISSAR.

Observer training proceeded in two stages. In the first stage of training the second observer memorized the MS-CISSAR codes and with the second author, 
practiced coding by watching videotapes of teachers in classrooms serving students with disabilities. Using the videotapes of teachers and students, the second observer and the second author achieved interobserver agreement across all categories at a minimum of $80 \%$. The second stage of training occurred in a classroom at the residential school for the deaf not used for this research study. The third author and the data collector observed the same teacher and the same student for at least 30 minutes per session. Reliability was confirmed when agreement across all categories was at or above $80 \%$ over three 30 minute sessions (range $80 \%$ to $100 \%$ ).

Procedures

Classroom observations were scheduled over the course of one semester. Each of the 13 teacher candidates was observed three times (39 observations). Each observation coincided with the schedule of the university supervising teacher. The second author, proficient in American Sign Language, conducted all the observations of the teacher candidates at the residential school for the deaf. The second observer conducted all the observations of the teacher candidates in the public school classrooms. Observers chose unobtrusive locations within the classroom. Interaction with the students was minimal.

\section{Results}

Thirteen teacher candidates were each observed three times during their semester of internship. They were observed for a total of 1480 minutes (24.7 
hours). Length of observation ranged from 27-66 minutes (mean 38 minutes). Eight interns taught at the residential school for the deaf. They taught students with and without additional disabilities in grades K-12. Five interns taught in either resource rooms or self-contained rooms. They taught students in grades K-5 who were labeled as learning disabled, trainable mentally handicapped, severe emotional disordered, or physically impaired.

\section{Research Question 1}

1. In what ways can ecobehavioral assessment data collected on special education teacher candidates during their internship experiences be incorporated as an assessment of their teaching behaviors?

First, the ecobehavioral assessment data can be accepted as evidence of teaching experience. The Director of the Intern Field Office accepted the MSCISSAR data as evidence of successful teaching for each teacher candidate. Second, teacher candidates can incorporate the MS-CISSAR data into their portfolios as data. Few teacher applicants have a research-based data-driven assessment of their teaching to show to potential principals. Third, the data can be used to assist teacher candidates in improving in specific areas. Because this was a field test, no intervention was implemented, but it would have been quite easy to identify problem areas and provide appropriate interventions for the candidates based on the MS-CISSAR data. Fourth, while the university forms call for a more 
global look at teaching, the MS-CISSAR data provided a data-driven description of the moment-by-moment events that occurred during the observation.

\section{Research Question 2}

What are the ecological arrangements (instructional grouping and tasks) used by the selected teacher candidates?

Teachers instruct students in various configurations. This is referred to as “instructional grouping” in the MS-CISSAR program. When teachers call small groups to work on the floor in the front of the room or call students to bring their chairs and form a circle near the calendar, the physical arrangement of desks remains the same, but the instructional grouping of the students changes. There are five codes for instructional groupings in the MS-CISSAR program: (a) whole class, (b) small group, (c) one-to-one, (d) independent and (e) no instruction. The preservice teacher candidates in the present study favored two instructional arrangements: whole class and independent. As shown in Table 1, teacher candidates used a whole class instructional arrangement an average of $59 \%$ of the time and independent workstations an average of $39 \%$ of the time. They used small group and one-to-one instruction rarely.

\section{Research Question 3}

What teacher behaviors are most commonly incorporated into lessons taught by teacher candidates? 
There are nearly 30 teacher behaviors recorded every cycle in the MSCISSAR program. Teachers either talk about academics, management, or discipline. Each category of academics, management, and discipline has three subcategories (a) command, (b) question, and (c) talk. For ease of data collection, the three subcategories of command, question, and talk were collapsed into the category of teacher talk. If, for example, a teacher disciplined a student and commanded her to sit down, we coded that command as discipline talk. Similarly, if a teacher asked a student an academic question, we coded the academic question as academic talk. Other codes for teacher behaviors include nonverbal prompting, paying attention, reading out loud, singing, and not responding. Observers also record whether or not the teacher indicates approval, disapproval, or neither; the focus of the teacher's attention; and the position of the teacher relative to the target student.

As shown in Table 2, the teacher candidates spent an average of $46 \%$ of their time engaged in academic talk. They attended to students an average of $15 \%$ of the time and nonverbally prompted students for an average of $12 \%$ of the time. The remaining time was spent not responding (13\%). Nonresponding is recorded when teachers are monitoring student work or when there are no questions. Nonresponding occurred most often during independent work time. The teacher candidates spent an average of $9 \%$ in management talk and $4 \%$ of their time disciplining students. (Management talk and discipline are different. Management 
talk refers to statements that assist the students in preparing to work, such as instructing students to gather their materials and meet in the front of the room; taking the lunch money to the office, etc.)

The teacher candidates demonstrated a neutral affect for an average of $85 \%$ of the time. A neutral affect is coded when the teacher candidate is not engaged in approval or disapproval. Much of teaching at each level is performed with a neutral affect. As shown in Table 2, teacher candidates indicated approval toward student behaviors (academic or otherwise) for an average of $11 \%$ of the time and disapproval toward student behaviors for an average of $4 \%$ of the time. Teacher candidates focused on students other than the target student for an average of $41 \%$ of the time and both the target and other students for an average of $31 \%$ of the time, as shown in Table 2 . The target student was the sole focus of attention for an average of $12 \%$ of the time.

\section{Research Question 4}

To what extent do the behaviors of randomly selected target students represent the following categories: academic responses, task management responses, and competing responses?

The randomly selected students engaged in three different kinds of behaviors: academic responses, task management, and competing behaviors. 


\section{Academic Responses}

There are five MS-CISSAR codes for academic responses: (a) writing, (b) task participation (i.e., using math manipulatives or typing), (c) reading aloud, (d) reading silently, and (e) talking about academics. As shown in Table 3, the randomly selected students in the classes taught by teacher candidates engaged in academic responding for an average of $42 \%$. They wrote for $15 \%$ of the time, read silently for $11 \%$, talked about academics for $8 \%$ of the time and participated in tasks for $7 \%$. They read aloud for less than $1 \%$ of the time.

\section{Task Management Responses}

Task management responses get the student ready to engage in academic responding. Task management responses include: (a) hand raising, (b) playing appropriately in teacher-sanctioned games, (c) manipulating materials (i.e., sharpening a pencil, gathering materials), (d) moving from one place to another, (e) talking about management issues (i.e., borrowing materials, talking about lining up), and (f) paying attention.

As seen in Table 3, the target students engaged in task management responses for an average of $47 \%$. Students engaged in passive attention for an average of $32 \%$. Students moved form one place to another for an average of $6 \%$. They manipulated materials for $5 \%$ of the time and raised their hands for $4 \%$. Playing appropriately and talking about management issues were recorded at less than $1 \%$ each. 


\section{Competing Behaviors}

There are seven behaviors that compete with academic responding: (a) aggression, (b) disruption, (c) inappropriate talk, (d) looking around, (e) noncompliance, (f) self-stimulation, and (g) self-abuse.

As seen in Table 4, the target students engaged in competing behaviors for an average of $18 \%$. The competing behavior most common to students was looking around. Students looked around for an average of $14 \%$. Target students talked inappropriately and engaged in disruptive behaviors each for an average of $2 \%$.

\section{Limitations}

The utility of these findings is limited. First, the sample was a small sample of convenience linked to two preservice special education teacher preparation programs in one university. This limits the generality of the findings beyond this project. Second, the presence of observers may have affected the behaviors of the teacher candidates and the students. All observations were scheduled ahead of time.

\section{Discussion}

In this field study we attempted to assess viability of incorporating the data gathered by the MS-CIKSSAR ecobehavioral assessment tool as acceptable evidence of the teaching behaviors of teacher candidates in special education. We additionally investigated the academic, task management, and competing 
behaviors of randomly selected students in their classrooms. The MS-CISSAR ecobehavioral assessment computer program was used to collect 24.7 hours of observational data on the instructional arrangements used by 13 special education teacher candidates, their teaching behaviors, and the academic responding, task management, and competing behaviors of randomly selected target students in the classes they taught.

Researchers have identified a causal path between instruction, student academic responding and academic achievement (Greenwood, Terry, et al., 1994). Although there are numerous variables inherent in the teaching/learning process, some behaviors and nonacademic skills contribute more to academic success (see DiPerna, Volpe, \& Elliott, 2002). One instructional variable that is alterable is "academic responding." Measurement of student academic responding in the presence of instruction by teacher candidates provides a data-driven snapshot of their teaching behaviors, their strengths in teaching and areas for improvement. Incorporating MS-CISSAR: The Teacher Trainer's Perspective

To prepare teacher candidates to use this as a meaningful tool, we provided two seminar sessions designed to familiarize teacher candidates with the literature on academic responding and strategies for interpreting the data they would receive. The integration of the MS-CISSAR in the traditional assessment process of teacher candidates presented few difficulties in providing meaningful feedback after each formal observation. Once the data are collected by the 
University Supervisor, several of the problems faced by the researchers in this study will resolve themselves. For example, the study required the presence of a second observer. Once university personnel are trained in the MS-CISSAR, program the data will be collected by one person. The start and stop times for each observation had to be coordinated. Although each feedback session was conducted within the same time frame of typical post conferences, both university supervisors and teacher candidates sometimes felt time constraints to adequately discuss all data. However, teacher candidates were encouraged to review all data on their own and later contact the University Supervisor if they needed further clarifications.

The benefits of the MS-CISSAR information outweighed the temporary challenges. During the post conference, each special education teacher candidate was able to immediately see, in graphed form, the results of the data collection. For example, it was easy to see how much time was spent in teaching vs. managing student behaviors or disciplining students. Teacher candidates could see how often the target student was academically responding and identify which behaviors competed for the teacher candidate's attention. As a supplement to each conference, each teacher candidate received a paper copy of the graphs and a teacher report. University supervisors noted that the conferences took on a new data-driven focus. Coupled with objective feedback in the form of frequencies and percentages, along with subjective feedback based on impressions of overall 
performance, each teacher candidate was provided with both a macro and micro view of the teaching episode.

Incorporating MS-CISSAR: The Teacher Candidate's Perspective

A post internship survey was administered to all 13 participants after all requirements for the internship were completed and the final grades were issued. The survey instrument (see appendix 1) asked 9 questions and was designed to gather teacher candidate feedback on the effects of the MS-CISSAR data on their teaching and what they learned from the additional data. The second question on the survey asked teacher candidates to "describe the effect, if any, that the data had on your teaching." One of the teacher candidates responded by saying that "the data helped me realize what areas I needed to improve on and [in] what areas [where] I was right on target." Another teacher candidate, responding to the same question, indicated that "the data helped me a lot. It showed me what areas that I needed to work on to better teach my class." Overall, the survey results indicated that the process of using the MS-CISSAR data, and the data themselves, gave teacher candidates a clearer picture of behaviors that did and did not occur, either by them or their students.

The MS-CISSAR data added an additional layer of information and feedback that the teacher candidates looked forward to receiving. Verbal feedback from the teacher candidates indicated that the additional data were not only beneficial but provided them with information that the typical intern evaluation 
tools did not provide such as frequency of interactions with specific students and the visual representation of their actual teaching behaviors. Teacher candidates also found it helpful to receive specific feedback on the behaviors of their target students during their instruction.

To test the value of the MS-CISSAR data, the university supervisor and the data collector provided only the MS-CISSAR data on the fourth and final post-observation conference. Feedback from the teacher candidates indicated that the MS-CISSAR data were just as helpful as the traditional feedback used during prior observation post-conferences.

\section{Ecological Arrangements}

Of the five possible instructional arrangements (whole group, small group, one-to-one, independent, and no instruction, the teacher candidates relied on two instructional arrangements: whole group (59\%) and independent work stations (39\%). Although whole group instruction is commonly used in smaller classes of 7 - 12 students, it is also associated with lower levels of academic responding (e.g., Greenwood, Delquadri, Stanley, Terry, \& Hall, 1985; Greenwood, Horton, \& Utley, 2002). Reliance on independent and one-to-one grouping arrangements can lead to higher levels of academic responding (Greenwood, Horton, \& Utley, 2002; Woolsey, 2001). There were no recorded instances of peer tutoring or cooperative group work. It is possible the instructional arrangements used by the teacher candidates in the present study may have been a function of candidates' 
desire to demonstrate their ability to teach. In future studies, university supervisors may use similar data to help teacher candidates develop skills in specific areas.

\section{Instructional Behaviors}

The teaching behaviors found in the teacher candidates were similar to the teaching behaviors demonstrated by teachers in other studies. This is both good news and bad news for the teacher candidates and the teacher educators.

The teacher candidates spent an average of $43 \%$ of their time engaged in academic questions, commands, or talk. The good news is this figure is somewhat higher than the amount of time in-service teachers spent in the same behaviors in other studies with elementary and middle school students as subjects (e.g., Kamps et al., 1991; Thurlow, Ysseldyke, Graden, Algozzine, 1984; Wallace, Anderson, \& Barholomay, 2001; Woolsey, 2001).

Although the teaching behaviors found in the teacher candidates were within ranges found in other studies, the bad news is that the levels could be significantly improved. One limitation to the MS-CISSAR program is the lack of descriptors for specific kinds of teaching behaviors. For example, there is no way to record whether or not a teacher is asking a higher level thinking question. The question is simply recorded as a question. This is an area where the university supervisor's observational report benefits the student significantly. 
If teacher candidates and teachers are looking to incorporate strategies that increase the academic responding of students during teacher-led lecture and discussion there are several research-based, low-tech, low-cost strategies that can increase the levels of student responding during whole class or small group instruction (Heward, 1994). Students can respond to yes/no or true/false questions with pre-printed response cards or write their answers on white boards. In a teacher-led discussion, the teacher poses a question and instead of one student answering at a time, each student in the class answers each question each time. When each student answers each question there is little doubt when students do or do not understand the material.

\section{Student Behaviors}

During the observations of the teacher candidates, the randomly selected target students engaged in more task management activities (47\%) than academic responding behaviors (42\%). This is another example of good news/bad news. The good news is that the randomly selected target students spent about as much time in task management activities as did students in classes with inservice teachers. In their study of students with and without disabilities in three elementary magnet schools, Greenwood, Horton, and Utley (2002) found that students spent more time in academic responding (46\%) than they did in task management responses (42\%). Both higher and lower percentages of academic responding have been recorded in other studies. 
The bad news is that passive attention and the other activities in task management are not correlated with academic achievement (Greenwood, Delquadri et al., 1984; Greenwood, Hart, Walker, \& Risley, 1994). The more time students spend in task management activities, the less time is available for academic responding.

Perhaps equally as bad were the levels of competing behaviors. The target students spent $14 \%$ of their time looking around and $4 \%$ of their time engaged in other competing behaviors. This level is higher than levels reported in other studies but may be explained by the level of classroom management competence of the teacher candidates and the addition of two observers.

\section{Conclusion}

We began this article by reviewing the pressures of accountability on teachers and teacher educators. While we are keenly aware that qualified teachers have a significant impact on student learning and that the quality of teacher preparation can account for $40 \%-60 \%$ of the variance in achievement after figuring for student demographics (Darling-Hammond, 2000), it is also true that many teacher preparation programs lack assessments of actual teaching performance (Wise \& Liebbrand, 2000). Many teacher preparation programs struggle with the provision of substantial evidence to answer this question: "Can this teacher candidate effectively teach?" 
Although our special education teacher preparation program still grapples with NCATE requirements and accountability standards, the MS-CISSAR data provided us and our teacher candidates with a data-driven profile of their teaching behaviors and the classroom responses of three students in their classroom. The data gathered through MS-CISSAR were objective and concise. We were able to compare teacher candidate performance to inservice teacher performances. Additionally we were able to compare student behaviors in the presence of teacher candidates to student behaviors in the presence of inservice teachers. The training process for the MS-CISSAR program takes approximately 30 hours. The investment is worth the effort. The MS-CISSAR data were accepted as evidence of teaching. The teacher candidates appreciated the addition of data during their post-conferences. The MS-CISSAR data pointed to areas of strengths and weaknesses in teacher candidates that, in future studies, can lead to interventions. The MS-CISSAR program is flexible. Teacher candidates could be observed with this program during their field experiences and at several points during their internship. This kind of data-timeline could clearly demonstrate that the teacher candidate in question can, indeed, effectively teach. 


\section{References}

Bulgren, J. A., \& Carta, J. J. (1993). Examining the instructional contexts of students with learning disabilities. Exceptional Children, 59, 182-191.

Cooper, D. H., \& Speece, D. H. (1990). Maintaining at-risk children in regular education settings: Initial effects of individual differences and classroom environments. Exceptional Children, 57(2), 117-126.

Darling-Hammond, L. (2000). Teacher quality and student achievement: A review of state policy evidence. Educational Policy Analysis Archives, 8. Available at http://epaa.asu.edu/epaa/v8n1.

Darling-Hammond, L., \& Youngs, P. (2002). Defining "highly qualified teachers": What does "scientifically-based research" actually tell us? Educational Researcher, 31 (9), 13-26.

DiPerna, J. C., Volpe, R. J., \& Elliott, S. N. (2002). A model of academic enablers and elementary reading/language arts achievement. School Psychology Review, 31, 293-297.

Gee, J. B. (2001). What graduates in education fear most about their first year of teaching. Paper presented at the annual meeting of the Louisiana Educational Research Association, Baton Rouge, LA.

Greenwood, C. R. (1991). Longitudinal analysis of time, engagement, and achievement in at-risk versus non-risk students. Exceptional Children, 57(6), 521-535. 
Greenwood, C. R., Arreaga-Mayer, C., \& Carta, J. J. (1994). Identification and translation of effective teacher-developed instructional procedures for general practice. Remedial and Special Education, 15(3), 140-151.

Greenwood, C. R., Carta, J. J., Kamps, D., \& Arreaga-Mayer, C. (1990).

Ecobehavioral analysis of classroom instruction. In S. Shcoreder (Ed.), Ecobehavioral analysis and developmental disabilities: The twenty-first century (pp. 33-63). New York: Springer-Verlag.

Greenwood, C. R., Carta, J. J., Kamps, D., Terry, B., \& Delquadri, J. (1994).

Development and validation of standard classroom observation systems for school practitioners: Ecobehavioral assessment systems software (EBASS). Exceptional Children, 61(2), 197-210.

Greenwood, C. R., Delquadri, J. C., \& Hall, R. V. (1989). Longitudinal effects of classwide peer tutoring. Journal of Educational Psychology, 81, 371-383.

Greenwood, C. R., Delquadri, J., Stanley, S. O., Sasso, G., Whoroton, D., \& Schulte, D. (1981). Allocating opportunity to learn as a basis for academic remediation: A developing model for teaching. Monograph in Behavioral Disorders, Summer, 22-33.

Greenwood, C. R., Delquadri, J. C., Stanley, S. O., Terry, B., \& Hall, R. V. (1985). Assessment of eco-behavioral interaction in school settings. Behavioral Assessment, 7, 331-347. 
Greenwood, C. R., Delquadri, J. C., Stanley, S. O., Terry, B., \& Hall, R. V. (1986). Performance-based assessment of depriving environments: Comparison of context/response interactions within inner-city and suburban school settings. In S. E. Newstead, \& S. H. Irving, \& D. P. Dan (Eds.), Human assessment: Cognition and motivation (pp. 319-340).

Greenwood, C. R., Hart, B., Walker, D., \& Risley, T. R. (1994). The opportunity to respond and academic performance revisited: A behavioral theory of developmental retardation and its prevention. In I. Gardner. R. \& D. M. Sainato, J. O. Cooper, T. E. Heron, W. L. Heward, J. Eshelmen, \& T. Grossi (Eds.), Behavior analysis in education: Focus on measurably superior instruction (pp. 213-239). Pacific Grove: Brooks/Cole.

Greenwood, C. R., Horton, B. T., \& Utley, C. A. (2002). Academic engagement: Current perspectives on research and practice. School Psychology Review, 31(3), 328-349.

Greenwood, C. R., Schulte, D., Dinwiddie, G., Kohler, F., \& Carta, J. J. (1986). Assessment and analysis of eco-behavioral interaction. In R. Prinz (Ed.), Advances in behavioral assessment of children and families (Vol. 2, pp. 69-98). Greenwich, CT: JAI Press.

Greenwood, C. R., \& Shye, L. H. (1995). Ecobehavioral assessment systems software (EBASS) technical manual (Version 3.0 ed.). Kansas City: Juniper Gardens Children's Project, The University of Kansas. 
Greenwood, C. R., Terry, B., Marquis, J. \& Walker, D. (1994). Confirming a performance-based instructional model. School Psychology Review, 23, $625-668$.

Heward, W. (1994). Three "low-tech" strategies for increasing the frequency of active student responding during group instruction. In R. Gardner, D. M. Sainato, J. O. Cooper, T. E. Heron, W. L. Heward, J. W. Eshelman, \& T. A. Grossi (Eds.), Behavior analysis in education: Focus on measurably superior instruction (pp. 283-319). Pacific Grove, CA: Brooks/Cole.

Kamps, D., Leonard, B. R., Dugan, E. P., Boland, B., \& Greenwood, C. R. (1991). The use of ecobehavioral assessment to identify naturally occurring effective procedures in classrooms serving students with autism and other developmental disabilities. Journal of Behavioral Education, 1(4), 367-397.

National Commission on Teaching \& America's Future. (1996). What matters most: Teaching for America's future. Report of the National Commission on Teaching \& America's future (report ED395931). New York: Author.

No Child Left Behind Act of 2001, Pub. L. No. 107-110, [sec] 115 Stat. 1425 (2002).

Rose, L. C., \& Gallup, A. M. (2002). The 34th annual Phi Delta Kappa/Gallup poll of the public's attitudes toward the public schools. Phi Delta Kappan, 84(1), 41-56. 
Sandholtz, J. H., \& Wasserman, K. (2001). Student and cooperating teachers: Contrasting experiences in teacher education programs. Action in Teacher Education, 23(3), 54-65.

Stanley, S. O., \& Greenwood, C. R. (1983). How much "opportunity to respond" does the minority disadvantaged student receive in school? Exceptional Children, 49, 370-373.

Thurlow, M. L., Ysseldyke, J. E., Graden, J., \& Algozzine, B. (1984). Opportunity to learn for LD students receiving different levels of special education services. Learning Disability Quarterly, 7, 55-67.

Tye, B. B., \& O'Brien, L. (2002). Why are experienced teachers leaving the profession? Phi Delta Kappan, 84(1), 24-32.

U.S. Department of Education. (2002). Meeting the highly qualified teachers challenge: The Secretary's annual report on teacher quality. (Inventory ID No. EP 0204P). Jessup, MD: Author.

Vogler, K. E. (2002). The impact of high-stakes, state-mandated student performance assessment on teachers' instructional practices. Education, 123(1), 39-55.

Wallace, T., Anderson, A. R., Bartholomay, T., \& Hupp, S. (2001). An ecobehavioral examination of high school classrooms that includes students with disabilities. Exceptional Children, 68(3), 345-359. 
Wideen, M., Mayer-Smith, J., and Moon, B. (1998). A critical analysis of the research on learning to teach: Making the case for an ecological perspective on inquiry. Review of Educational Research, 68(2), 130-178.

Wise, A. E., \& Liebbrand, J. A. (2000). Standards and teacher quality. Phi Delta Kappan, 81(8), 612-621.

Woolsey, M. L. (2001). The use of ecobehavioral analysis to identify the critical behavioral variables in two types of residential classrooms for students who are deaf (Doctoral dissertation, The Ohio State University, 2001). Dissertation Abstracts International, 62, 2729. 
Appendix

Post Internship Survey

for

An Ecobehavioral Assessment of the Teaching Behaviors of Teacher candidates

Serving De Students and Students with varying Exceptionalities

Please respond to each of the 9 questions below. Your response will remain confidential.

Please indicate if you were a:

(a) __ Deaf Education Intern or a ___ Varying Exceptionalities Intern

(b) __ male or __ female

(c) minority

1. Describe the effect, if any, of having additional people observe you during the regularly scheduled observations.

2. Describe the effect, if any, that the data had on your teaching.

3. Describe the effect, if any, that the data had on the behavior of your students.

4. Describe the effect, if any, that the meetings with your intern supervisors had on your teaching.

5. As a result of participating in this study, what do you know now that you didn't know before about teaching and learning?

6. Would you recommend the use of the computer program for the evaluation of instruction for future interns? Why/why not?

7. If you could repeat your internship experience and be observed, what would you do differently?

8. What kinds of information do you think teacher interns need?

9. What information would you like the researchers to know? 
Teacher Candidate Assessment 35

Table 1

Mean Instructional Groupings

$\begin{array}{cc}\text { Instructional Grouping } & \text { Mean Percent } \\ \text { Whole Class } & 59 \% \\ \text { Small Group } & 1 \% \\ \text { One-on-One } & 1 \% \\ \text { Independent } & 39 \%\end{array}$




\section{Table 2}

Mean Special Education Teacher Candidates Behaviors

Teacher Candidates Behaviors Mean Percent

Academic Talk $\quad 46 \%$

Attention $\quad 15 \%$

Nonverbal Prompts $\quad 12 \%$

No Response $\quad 13 \%$

Talk Management $\quad 9 \%$

Discipline $\quad 4 \%$

$\begin{array}{lc}\text { Teacher Affect } & \text { Mean Percent } \\ \text { Neutral Affect } & 85 \% \\ \text { Approval Affect } & 11 \% \\ \text { Disapproval Affect } & 4 \% \\ & \\ \text { Teacher Candidate Focus } & \text { Mean Percent } \\ \text { Other Students } & 41 \% \\ \text { Target Student \& Others } & 31 \% \\ \text { Target Student } & 12 \%\end{array}$


Table 3

Mean Academic Responses and Task Management Student Responses

Academic Responses

Mean Percent

Writing

$15 \%$

Reading Silently

$11 \%$

Talk Academic

$8 \%$

Task Participation

$7 \%$

Reading Aloud

$<1 \%$

Total

$42 \%$

$\begin{array}{lc}\text { Task Management Responses } & \text { Mean Percent } \\ \text { Attention } & 32 \% \\ \text { Move } & 6 \% \\ \text { Manipulating Materials } & 5 \% \\ \text { Hand Raise } & 4 \% \\ \text { Talk Management } & <1 \% \\ \text { Play Appropriate } & <1 \% \\ \text { Total } & 47 \%\end{array}$


Table 4

Mean Competing Student Behaviors

Competing Behaviors

Mean

Aggression

$0 \%$

Disruption

$2 \%$

Inappropriate Talk

$2 \%$

Looking Around

$14 \%$

Noncompliance

$0 \%$

Self-Stimulation

$0 \%$

Self-Abuse

$0 \%$

Total

$18 \%$ 